\title{
ANALYSIS OF INTERNATIONAL STANDARDS ON CONCRETE REINFORCING STEEL BAR*
}

\author{
Jorge Madias ${ }^{1}$ \\ Michael Wright ${ }^{2}$ \\ Gustavo Behr ${ }^{3}$ \\ Vanessa Valladares ${ }^{47}$
}

\section{Resumo}

O trabalho está centrado na análise comparativa de normas de vinte paises/regiões sobre vergalhão, escolhidos levando em conta os principais paises productores, exportadores, e consumidores deste produto para a construção civil. São comparadas as propriedades mecânicas: limite de escoamento, resistência à tração, elongamento à rotura, elongamento uniforme, relação escoamento/tração), a análise química, testes especiais como fadiga e adherência e outros ítens. Tambén é tida em conta a evolução dos quesitos das normas ao longo do tempo. O foco é o comportamento anti seismo do vergalhão.

Palavras-chave: Vergalhão; Propriedades mecânicas; Normas; Comportamento em sismos.

\section{ANALYSIS OF INTERNATIONAL STANDARDS ON CONCRETE REINFORCING STEEL BAR}

\section{Abstract}

The paper is centered in a comparison of reinforcing steel bar standards of twenty countries / regions, selected on the base of rebar production, exports and application. The comparison includes mechanical properties (yield strength, tensile strength, elongation to rupture, uniform elongation, strain hardening ratio); chemical composition; special tests like fatigue and adherence, and other items. The evolution of the requirements along time is taken into account, too. The focus is on the seismic behavior of concrete reinforcing bar.

Keywords: Reinforcing bar; Mechanical properties; Standards; Seismic behavior.

Metallurgical Engineer, Director, metallon, San Nicolas, Buenos Aires, Argentina.

B.A.Sc. - Materials, Senior Technical Consultant, Modern Metal Consulting, Singapore.

Engineer, Technical Director - Rolled Products, ADELCA, Aloag, Pichincha, Ecuador.

Engineer, Quality Manager - Rolled Products, ADELCA, Aloag, Pichincha, Ecuador.. 


\section{INTRODUCTION}

The standards usually reflect with a certain delay the advances of technology in product manufacturing and the growing requisites of the users. In this paper, national, regional and international standards on steel reinforcing bar are analyzed. This is a product for which the standards have a low degree of globalization: the penetration of the corresponding ISO standard is low, and national standards are still dominant. The review includes mechanical properties, bending and re-bending, and chemical analysis; other aspects like traceability, fatigue and adherence are briefly addressed.

The aim is to verify trends in the quality constraints that may affect the commercialization and application of rebar. Specifically, the requisites related with seismic behavior and the influence of manufacturing processes (natural hardness, on-line quenching and tempering, micro-alloying). First, the standards to be analyzed are listed, then each of the researched properties are discussed. Previous papers by the authors on related subjects are used as background [1-3].

The countries selected and the corresponding standards are presented in Table 1. Reasons behind the choice have to do with different situations: rebar exporting potential; high seismicity; high rebar production; special features of the standard. In some countries, a single standard cover not only rebar but other long products for civil construction (generally round bars, but in some cases welded mesh, pre-stress concrete, etc.). ASTM standards and their followers have usually two standards: one for reinforcing bar in general, and other for weldable rebar. Still there are in some countries standards for rebar produced by rolling rail or strip scrap. Those standards are not taken into account in this study.

Table 1. Countries / regions selected, corresponding standards and character of the standard

\begin{tabular}{|l|c|c|c|}
\hline Country & Standard & Character & Ref. \\
\hline \multirow{2}{*}{ Argentina } & IRAM-IAS U500-207 2004 & Weldable & 4 \\
\cline { 2 - 4 } & IRAM-IAS U500-528 2004 & General & 5 \\
\hline Australia/N. Zealand & AS/NZS 4671:11 & General & 6 \\
\hline Brazil & ABNT NBR7480 & General & 7 \\
\hline Canada & G30.18-09EN reaffirmed 2014 & General & 8 \\
\hline Chile & NCh 204 & General & 9 \\
\hline China & GB 1499.2 2007 & General & 10 \\
\hline Colombia & NTC 2289 2007 & General & 11 \\
\hline Ecuador & NTE INEN 102:2015 & General & 12 \\
\cline { 2 - 4 } & NTE INEN 2167:2015 & Weldable & 13 \\
\hline Europe & prEN 10080 2005 & General & 14 \\
\hline Germany & DIN 488.1 2009 & Grades, properties, marking & 15 \\
\cline { 2 - 4 } & DIN 488.2 2009 & General & 16 \\
\cline { 2 - 4 } & DIN 488.6 2010 & Conformity assessment & 17 \\
\hline International & General & 18 \\
\hline Japan & JIS G35-2 2015 Part 2 & General & 19 \\
\hline Mexico & NMX-C-407-ONNCCE-2001 & General & 20 \\
\cline { 2 - 4 } & NMX-B-457-Canacero-2013 & Weldable & 21 \\
\hline Peru & PNTP 341 331 2015 & General & 22 \\
\cline { 2 - 4 } & PNTP 339 186 2015 & Weldable & 23 \\
\hline Spain & UNE 36065 2011 & High ductility & 24 \\
\hline & UNE 36068 2011 & Weldable & 25 \\
\hline Taiwan & CNS 560 2005 & General & 26 \\
\hline
\end{tabular}




\begin{tabular}{|l|c|c|c|}
\hline Turkey & TS 708 2010 & General & 27 \\
\hline United Kingdom & BS 4429 2005 & General & 28 \\
\hline \multirow{2}{*}{ USA } & ASTM A 615-14 & General & 29 \\
\cline { 2 - 4 } & ASTM A 706-14 & Weldable & 30 \\
\hline Vietnam & TCVN 1651-2 2008 & General & 31 \\
\hline
\end{tabular}

\section{MECHANICAL PROPERTIES}

A comparison of mechanical properties was carried for the standards in table 1 , including tensile and yield strength, stress ageing ratio, uniform elongation and elongation to rupture. The main variable, present in all the standards reviewed, is yield strength. Some standards define a minimal value, others both minimum and maximum. The lowest value corresponds to one of the grades of the Turkish standard (220 MPa), while the maximum (600 MPa) belongs to one of the grades of the ISO standard.

Some South American standards have a high strength grade of $420 \mathrm{MPa}$ minimum, the classic grade 60 of ASTM, the highest in the 1970's. Instead, the Japanese and Taiwanese standards have $490 \mathrm{MPa}$ grades, several other standards meet a high strength grade of $500 \mathrm{MPa}$ minimum: Australia/New Zealand, Brazil, Canada, China, Spain, United Kingdom, Turkey and Vietnam. ASTM standards include a $550 \mathrm{MPa}$ (ASTM A615 included this grade in 2014, for compatibility with ASTM A706). Ecuador and one of the Mexican standards include $550 \mathrm{MPa}$ grades. In Germany the two existing grades have $520 \mathrm{MPa}$ minimum, and there are no grades with less strength (neither the British standard). In figure 1, the minimum yield strength for the higher grades are compared.

Some Asian countries are considering the introduction of 600 MP minimum grade, as in ISO standard. Some arguments favoring high strength rebar from the point of view of constructors are reducing rebar congestion existing in anti seismic design, particularly in column-beam crossings (Figure 2), and reducing total steel mass needed for the overall construction.

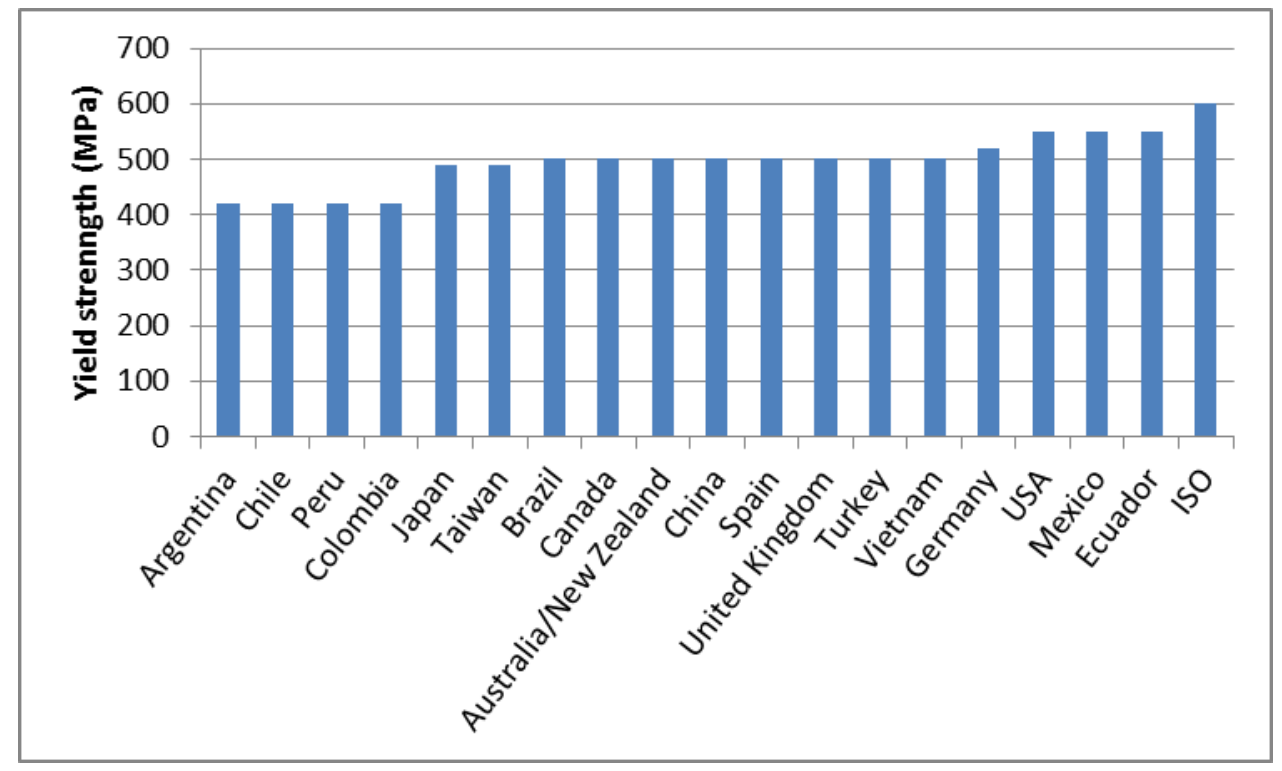

Figure 1. Minimum yield strength, in MPa, of the high strength grades of the reviewed standards. 


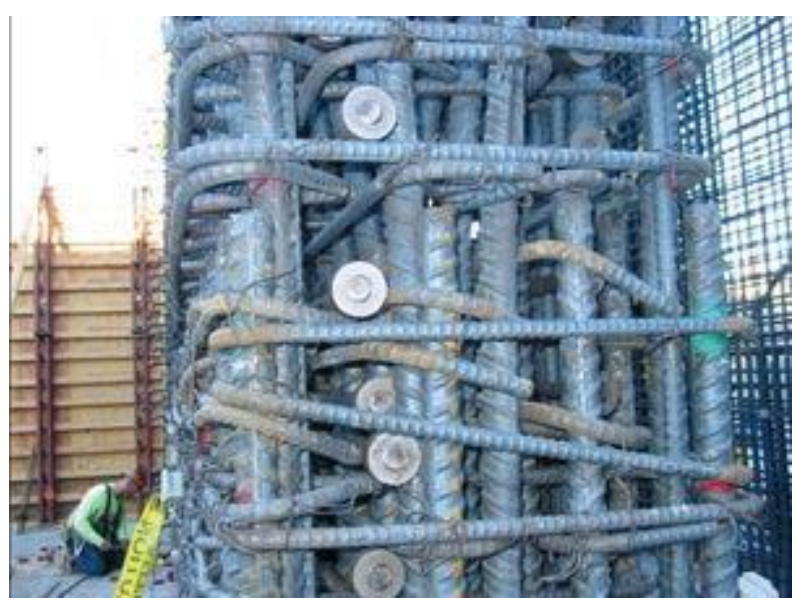

Figure 2. Rebar congestion on beam / column crossings in a high-rise building of a seismic zone (Southern California, USA).

Regarding elongation, most standards prefer elongation to rupture; others, uniform elongation. This value is the elongation for the maximum load, more complex to measure (an extensometer is required). For instance, the German standard changed to uniform elongation in 2009. Four standards within the population reviewed define minimum values for uniform elongation: China, Spain, Vietnam and some grades of the Turkish standard.

The relationship between minimum yield strength and minimum elongation to rupture requested by the standards is clear (Figure 3 ). The highest elongation to rupture is requested by the high ductility Spanish standard, the grade A55 of the Ecuadorian standard and the grades B600 of the ISO standard.

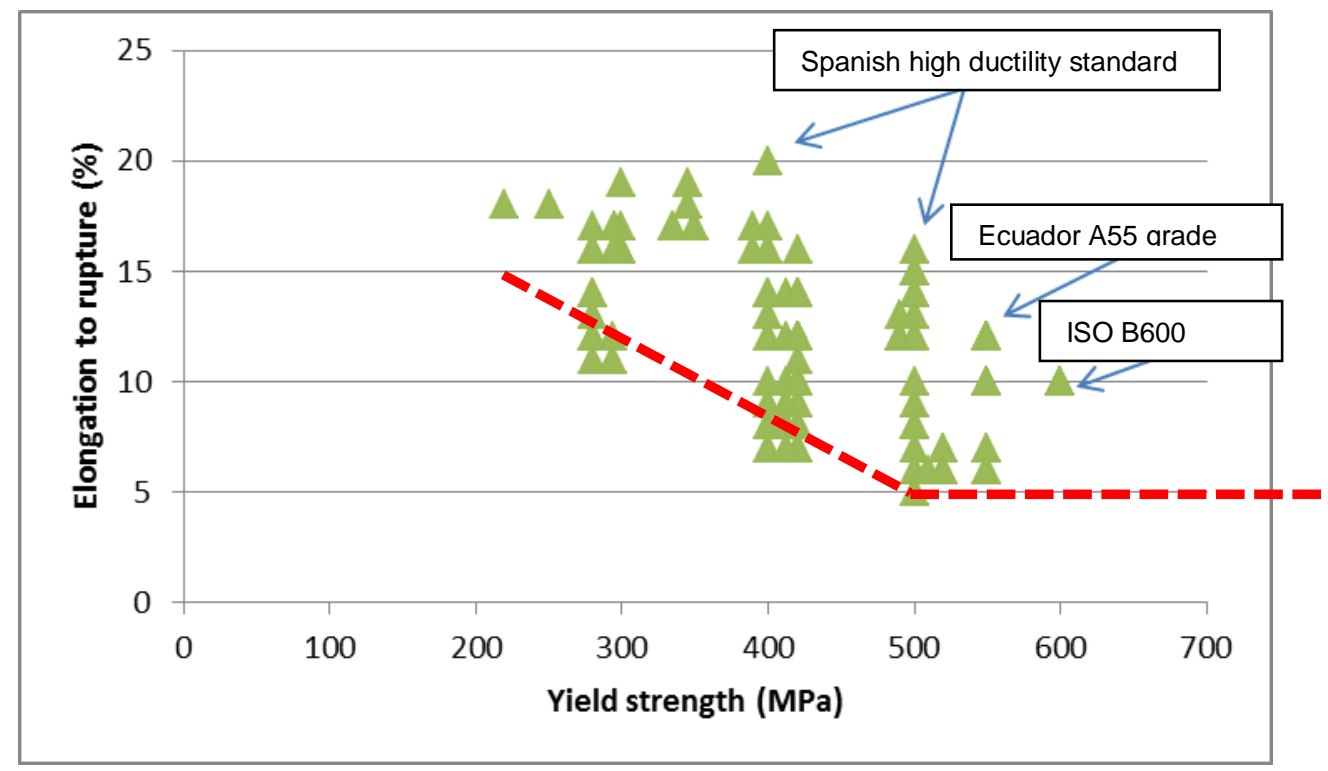

Figure 3. Relationship between minimum elongation to rupture and minimum yield strength, according to the standards.

The standard of Australia and New Zealand defines three ductility degrees:

- low (an $L$ is added to the bar designation);

- normal (an $\mathrm{N}$ is added to the bar designation)

- high or seismic (an E is added to the bar designation). 
Type $\mathrm{E}$ corresponds to 2 levels of minimum yield strength ( 300 and $500 \mathrm{MPa}$ ). In this case, a very high uniform elongation is requested (15 and 10\% respectively) and a tensile strength / yield strength ratio of at list 1.15. In the considerations of the standard it is mentioned that it is not expected a consumption of $500 \mathrm{E}$ grade in Australia, as it is a low seismicity country. Instead, for New Zealand market this is a very important grade.

In Figure 4 the relationship between minimum yield strength and minimum uniform elongation is presented. There are less points than in figure 3 , as not so much standards request uniform elongation. Anti seismic grades of New Zealand are located in a range of high uniform elongation, compared with other standards. Only the anti seismic high-strength Chinese grade is close to them.

The question is "why is $5 \%$ elongation to rupture considered acceptable in higher yield strength rebar?" See figure 5. Experience suggests that the minimum acceptable elongation to rupture (\%) in rebar is dictated by what can reasonably be achieved in a high yield strength steel made with simple C-Mn metallurgy. But at what "elongation to rupture (\%)" would a metal be seen to be classed as "brittle"?

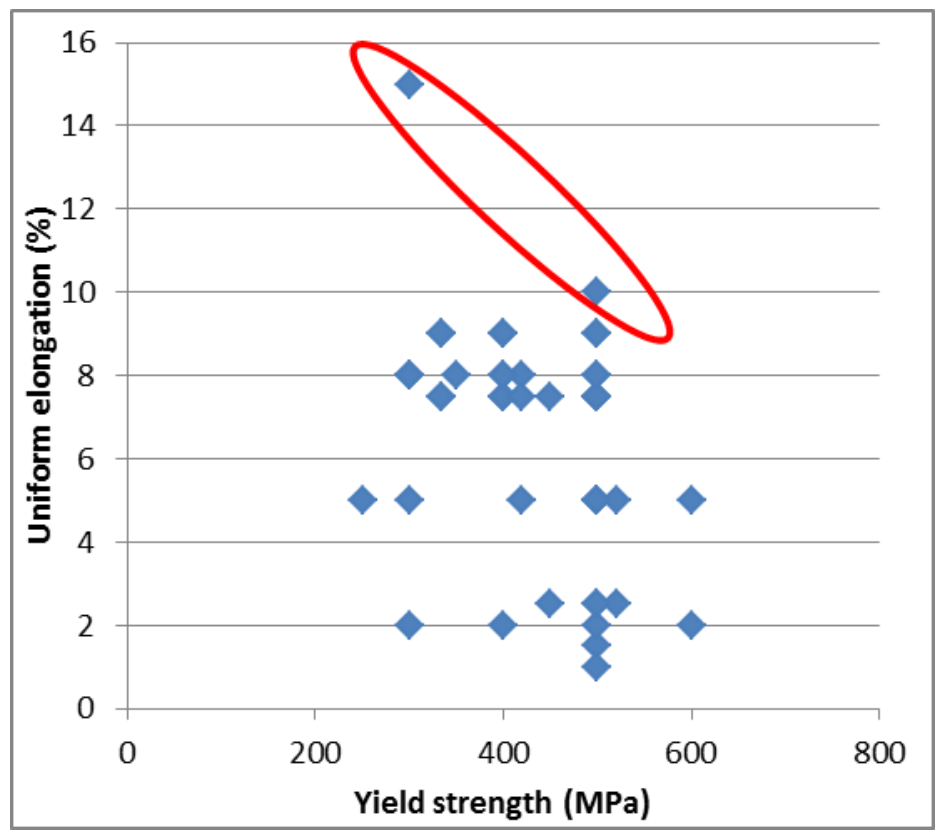

Figure 4. Relationship between minimum yield strength and minimum yield. The range of high uniform elongation, corresponding to the two seismic grades of the Australia - New Zealand standard is highlighted.

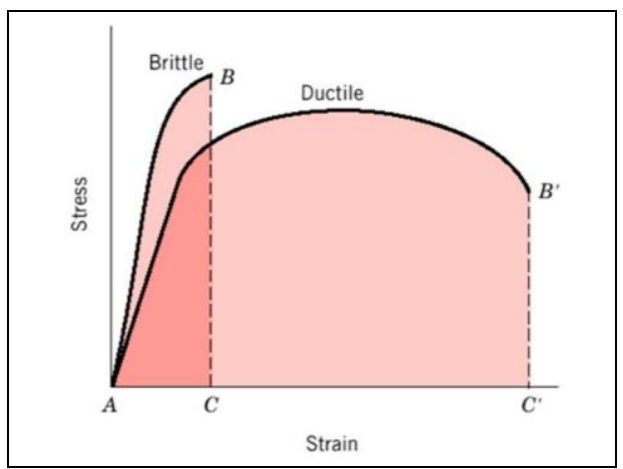

Figure 5. Schematic stress-strain curve, showing typical ductile and brittle behavior. 
The reason for this question is that in a concrete-steel composite material, the concrete is a brittle material - if the steel is also brittle, then the entire structure can be classed as brittle. The ductile properties can only originate in the steel, so this property must be protected by Standards.

Regarding the tensile strength / yield strength ratio (also called strain hardening ratio), only one standard defines a single low value (the German, 1.08). The standards of ISO, Australia/New Zealand, Brazil, USA, United Kingdom, Mexico, China and Turkey establish high values for some grades and low values (or no value) for others. Only high values are defined by the standards of Argentina, Canada, Chile, Colombia, Ecuador, Peru, Spain and Japan (in this case by agreement between supplier and purchaser).

The standards establishing the highest ratio (1.25) are ASTM A706, both Argentine standards, the Mexican NMX-B-457 standard and the Chilean, Colombian, Ecuadorian and Peruvian standards. Taiwan and China, just for some grades. The Spanish standard for high ductility rebar, one of the grades of the Turkish standard, and the Canadian standard request 1.20 minimum. The standard of Australia and New Zealand establish 1.15 minimum for the seismic grades.

Here have been argumentations showing that the high ratio requested by ASTM A706 has been a limiting factor for the application of the processes for on-line quenching and self-tempering, that are in broad use worldwide, due to lower cost and weldability, except in the USA [32].

There is no relationship between the strain hardening ratio and the yield strength, as well as with elongation to rupture (Figures 6 - 7). Instead, with uniform elongation the relationship is clear (Figure 8). Two values escaping from the curve are again those corresponding to the anti seismic grades of Australia/New Zealand.

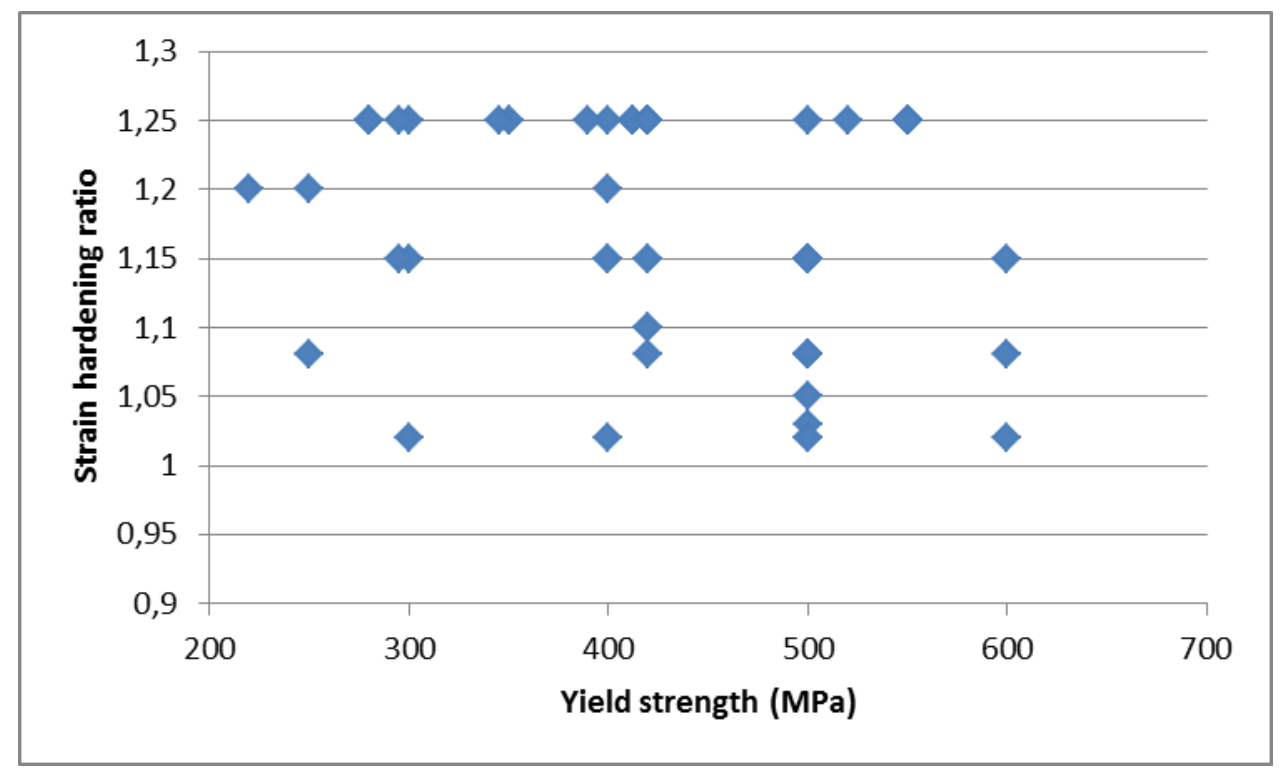

Figure 6. Relationship between minimum yield strength and minimum strain hardening ratio, as requested by the standards. 


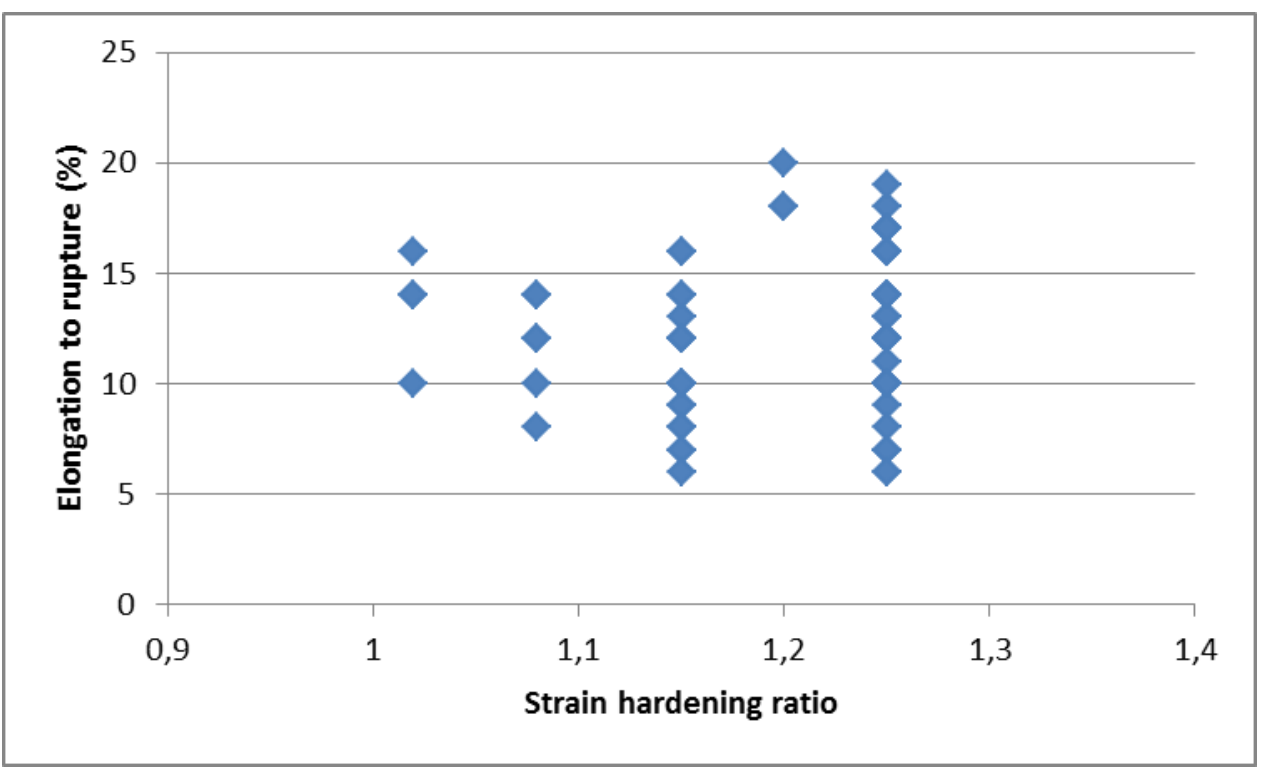

Figure 7. Relationship between minimum elongation to rupture and minimum strain hardening ratio requested by the standards.

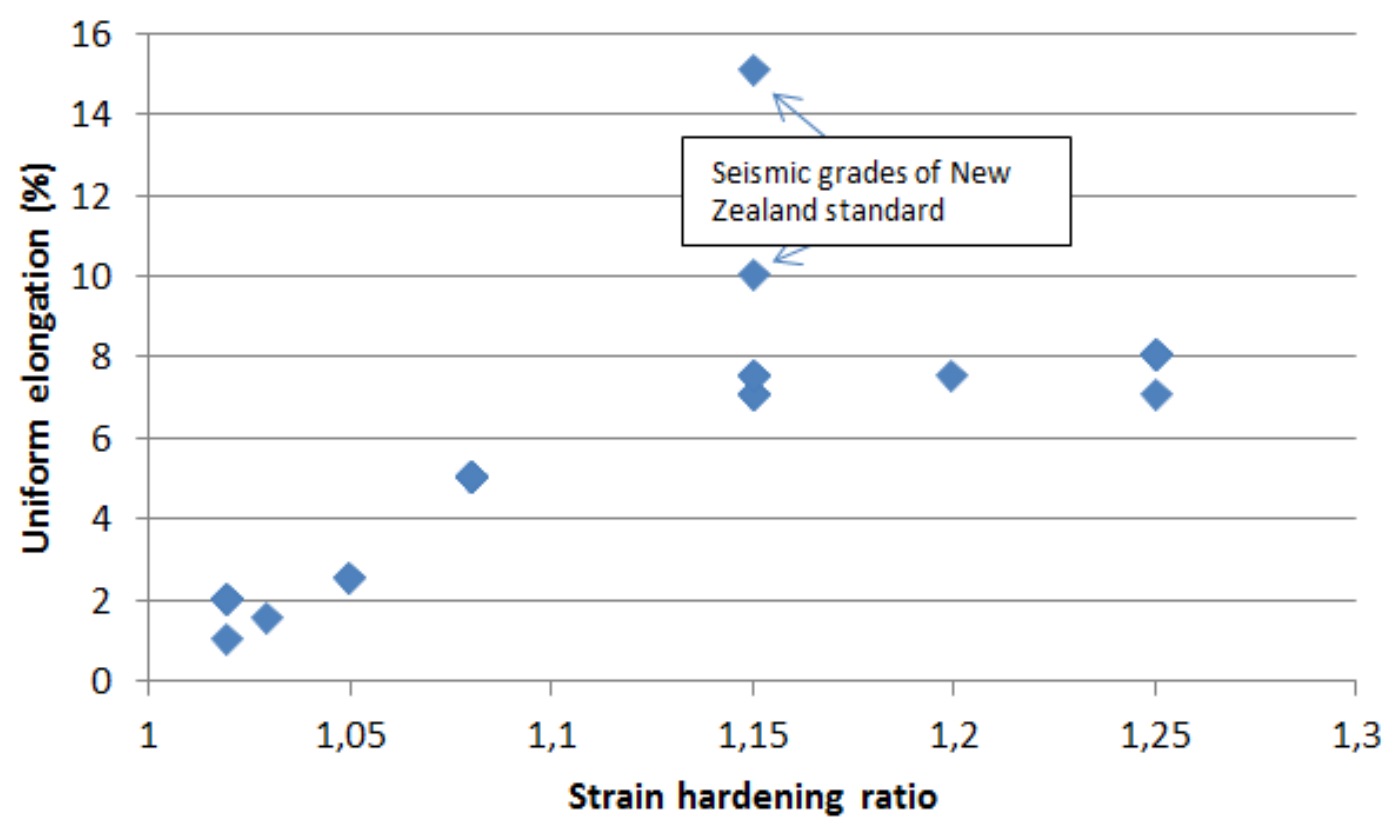

Figure 8. Relationship between minimum uniform elongation and minimum strain hardening requested by the standards.

\section{BENDING AND REBENDING}

To assess the bending aptitude, most standards use bending to $180^{\circ}$, defining the mandrel diameter as a function of the nominal diameter of the bar. An exception is the Chilean standard, using $90^{\circ}$ bending. Some standards prefer $90^{\circ}$ bending only for the large diameter bars and/or the very high strength grades. European standards like the Spanish and British standards prefer bending and rebending to evaluate bending aptitude, with an intermediate ageing. The German standard do the same but only for bars of less than $40 \mathrm{~mm}$ diameter. 
The introduction of magnetized particles testing, a more objective tool than just naked view, to assess if cracks are present after bending, common for other steel products, is not yet considered by rebar standards.

\section{CHEMICAL ANALYSIS}

The values fixed for chemical analysis are usually maximum content. There are usually two chemical analysis specifications: heat analysis and product analysis. Values for product analysis are typically $10 \%$ higher than for heat analysis. Only the standards of Brazil and Chile do not have chemical requirements. Others, like ASTM A615 and followers, establish only maximum P content. ASTM A 706 (weldable rebar) and followers, establish maximum values for $\mathrm{C}, \mathrm{Mn}, \mathrm{P}, \mathrm{S}$ and $\mathrm{Si}$. Other standards do the same, for high ductility / weldable rebar. As is logic, they establish a maximum value for equivalent carbon, too. There are three different criteria for its calculation.

ISO, the European countries standards, China and one of the Argentina standards define a maximum value for nitrogen, too. It is generally $0.012 \%$, for some grades. Some meltshops based in obsolescence scrap would be complicated for fulfilling such limit. This limit is relaxed when there are nitride-former elements, like Al, B. Nb, $\mathrm{Ti}$ or $\mathrm{V}$. The South African standard, not included in this review, fixes the lowest nitrogen value: $0.080 \%$, but only for oxygen steelmaking steels, where this maximum content is easily achieved.

The European standard defines a maximum content for copper: $0.80 \%$; the German standard, $0.60 \%$. These are values easy to achieve, although it is worth to mention that copper content in scrap and steel increase as the steel is recycled. The Canadian standard establish special chemistry requirements for galvanized rebar ( $\mathrm{Mn}$ and Si are more restricted than usual).

Of course, steel plants have always internal specifications more restrictive than those in the standards. This is to make sure they obtain the required mechanical properties at lower cost, but also to minimize surface and internal quality problems, as those related with high sulphur or high copper.

The lowest phosphorus content is present in the ASTM standard for weldable rebar, and its followers from Mexico, Colombia, Ecuador and Peru: $0.035 \%$, a value easy to obtain with current EAF processes with high oxygen injection. The lowest sulphur value is $0.040 \%$; so is specified for weldable grades of ISO standard, one of the Ecuador standards, four Japanese grades, two weldable grades in Taiwan and Vietnam. This value may sporadically bring about trouble, in meltshops operating with high percentage of low-quality scrap.

The lowest carbon content is $0.22 \%$, established by the standards in Europe, Spain, Germany, Turkey and Argentina (in the two last cases, just for weldable rebar).

Only some of the standards establish manganese content. The maximum oscillate between 1.50 and 1.80, well above usual values (although with this element there are at times, in certain cases, variations along the heat that may affect product analysis). In general, the standards reflect with a long delay the advancement of steelmaking technology. Specifications are so relaxed that in very few cases chemistry could be out of a standard. A relative exception is weldable / high ductility rebar, where $\mathrm{C}, \mathrm{Mn}$ and residual elements are to a certain extent under control. There is a growing trend to establish weldability / high ductility requirements.

\section{SPECIAL TESTS}


Some rebar standards introduce as compulsory or optional, testing on fatigue and adherence. The fatigue test with axial load is one more requisite on mechanical properties, in the German, British and Spanish standards (in this last case just for the high ductility rebar). For the European standard fatigue test is an option, but its application is very thoroughly detailed. For Argentina, China, and Australia / New Zealand standards, fatigue test may be carried out if so is agreed between purchaser and manufacturer. ASTM standards and followers, as well others standards like those of Chile, Taiwan, Turkey and Vietnam do not mention fatigue.

Regarding the adherence of the rebar to the concrete, most standards do not even mention it. The European standard defines adherence as given by the geometry of ribs, but that it can be verified by beam test or pull test. Both tests are described in appendices detailing preparation, equipment, procedure and report. The British standard present a similar criteria, but takes beam test as the alternative testing tool. Australia / New Zealand presents a calculus for the estimation of adherence in function of the surface of ribs; uses pull test as an alternative.

\section{NON-STANDARD GOVERNMENTAL MEASURES}

Some governmental measures go beyond the standards regarding rebar specifications. As an example, in Argentina and Ecuador national resolutions establish a certification system for civil construction steel products [33-34]. Instead, the European criteria is to include these certification system in the standards [14].

The influence of the mechanism utilized by the manufacturer to achieve the required mechanical properties tends to be taken into account, as it influences behavior in use (corrosion, fire strength, seismic behavior) [35]. As an example, the Department of Building and Housing of New Zealand issues Practice Advisory that establish how to use the anti seismic grade rebar, taking into account if it was produced using microalloying or on-line quenching and tempering [36]. For example (MA means microalloyed and QT means on-line quenched and tempered):

- Cold re-bending/straightening of Grade 500E MA and QT are not permitted by NZS 3109.

- Welding of Grade 500E QT is not permitted by NZS 3109.

- Site welding of Grade 500E MA should be avoided.

- Shop welding (but not tack welding) of Grade 500E MA is considered acceptable provided that evidence is presented that the procedures used do not affect compliance of the reinforcement with AS/NZS 4671.

In certain countries, not only the producer name or logo must be rolled in the bar, but the name of the importing company, is such is the case. Foreign manufacturers introducing rebar in Germany must roll in the rebar a specific mark given by a local association [37].

\section{CONCLUSIONS}

Analyzing the rebar standards, some trends can be verified:

- Mechanical properties: There is a trend to include high yield grades, over $500 \mathrm{MPa}$, aiming to decrease bar congestion, particularly in column / beam crossings in high-rise buildings for seismic zones. A clear relationship between yield strength and elongation surges from the standards, but in seismic or high 
ductility grades higher minimum elongation is required. The New Zealand standard is an example.

- Strain ageing ratio: there is an ample scope of specifications, from standards that have no requirement at all, to those requesting a low ratio, to some requesting a high ratio. In an intermediate situation are various countries establishing lower or higher values depending on the grade, or having directly two standards, one with high ratio and the other with low ratio. In general, seems to be a consensus, for high seismicity countries, in having minimum ratios of 1.15 or higher. This ratio has a clear relation with uniform elongation.

- Bending and rebending: Most standards establish bending at $180^{\circ}\left(90^{\circ}\right.$ being reserved in some standards for the larger diameters or higher strength. European-influenced standards prefer bending and rebending.

- Chemical analysis: No restrictions in the Brazilian and Chilean standards. The other standards, at least for the weldable or high ductility grades, request maximum equivalent carbon, generally accompanied by maximum content of carbon and other elements. There are three different criteria applied for calculation of equivalent carbon. The trend to establish weldable / high ductility grades is growing. Those grades exist in essentially all the countries taken into account, although not always in a separate standard. In fact, in some countries, particularly in Europe, only weldable / high ductility grade exist. Most critical chemistry requirements are those with a low maximum carbon content (0.22-0.25\%) and a maximum nitrogen content (generally $120 \mathrm{ppm})$. This last may complicate meltshops using 100\% obsolescence scrap.

- Other tests. Fatigue and adherence testing start to occur as a requisite in some European standards; in other standards they are just an option and finally in other cases they are not even mentioned. Grain size, a fairly common requisite in standards for other steel products, is only mentioned in the Chinese standard. Traceability becomes more and more relevant, taking into account the intervention of several manufacturers of different countries for a given product.

Some aspects that should be taken into account when updating standards are:

- Introduction of minimum uniform elongation, rather than elongation to rupture, as a more fundamental requisite for seismic / high ductility purposes.

- Introduction of magnetized particles testing to assess if cracks are present after bending

- Maximum grain size should be considered for seismic / high ductility purposes, as well as lower phosphorus and sulphur contents.

- As international trade of billets intended for rebar rolling becomes more important, traceability should be emphasized.

- The request of conformity assessment by third parties

- The mechanism utilized by the manufacturer to obtain the properties becomes more important, as it influences future performance (corrosion, seismic behavior, strength after fire)

\section{REFERÊNCIAS}

1 Wright, M.; A comparison of current global standards and future directions. SEAISI Conference and Exhibition, 2013, pp. 1-14.

2 Madias, J.; Wright, M.; A comparative study on reinforcing steel bar standardization. Research Report for IChA, Instituto Chile del Acero, April 2015 
3 Madias, J.; Wright, M.; Review of twenty standards on reinforcing steel bar. Research Report for ADELCA, January 2016

4 IRAM-IAS U 500-528 Barras de acero conformadas de dureza natural, para armadura en estructuras de hormigón. $5^{\text {a }}$ edición, 2004.06.28. IRAM Buenos Aires, Argentina.

5 IRAM-IAS U 500-207 Barras de acero conformadas de dureza natural soldables, para armadura en estructuras de hormigón. $2^{\mathrm{a}}$ edición, 2004.06.28. IRAM Buenos Aires, Argentina.

6 AS/NZS 4671:2001 Steel reinforcing materials. Council of Standards Australia 18 January 2001, Council of Standards New Zealand 9 March 2001.

7 ABNT NBR7480 Aço destinado a armaduras para estruturas de concreto armado Especificação. Associação Brasileira de Normas Técnicas, Rio de Janeiro, Brasil, 03/09/2007.

8 G30.18-09EN reaffirmed 2014 Carbon steel bars for concrete reinforcement. Canadian Standards Association.

9 NCh204-2006 Acero - Barras laminadas en caliente para hormigón armado. Instituto Nacional de Normalización, Santiago, Chile, 2006.

10 GB1499 2-2007 Steel for the Reinforcement of Concrete- Part 2: Hot Rolled ribbed Bars (English version). Standardization Administration of the People's Republic of China, Beijing, China, August 14, 2007.

11 NTC 2289 Barras corrugadas y lisas de acero de baja aleación, para refuerzo de concreto. Instituto Colombiano de Normas Técnicas y Certificación (ICONTEC), Bogotá, Colombia, 2007.12.12.

12 NTE INEN 102-2015 Varillas corrugadas y lisas de acero al carbono laminadas en caliente para hormigón armado. Requisitos. Instituto Ecuatoriano de Normalización, Quito, Ecuador.

13 NTE INEN 2167-2015 Varillas de acero lisas y/o con resaltes, laminadas en caliente, soldables, microaleadas o termotratadas, para hormigón armado. Requisitos. Instituto Ecuatoriano de Normalización, Quito, Ecuador.

14 prEN 10080 Steel for the reinforcement of concrete - Weldable reinforcing steel General. European Committee for Standardisation, January 2005.

15 DIN 448-1.1 2009-08 Reinforcing steels - Part 1: Grades, properties, marking (English Translation). DIN Deutsches Institut für Normung e. V., Berlin, Germany

16 DIN 448-1.2 2009-08 Reinforcing steels - Reinforcing steel bars (English Translation). DIN Deutsches Institut für Normung e. V., Berlin, Germany.

17 DIN 448-1.6 2010-01 Reinforcing steels - Part 6: Assessment of conformity (English Translation). DIN Deutsches Institut für Normung e. V., Berlin, Germany.

18 ISO 6935-2 2015 Steel for the reinforcement of concrete - Part 2 Ribbed bars. International Standards Organization, Geneva, Switzerland, 2015.

19 JIS G3112-2010 Steel bars for concrete reinforcement (English version). Japanese Industrial Standards, Tokyo, Japan, September 2010.

20 Norma Mexicana NMX-B-457-CANACERO-2013 Industria siderúrgica - Varilla corrugada de acero de baja aleación para refuerzo de concreto - Especificaciones y métodos de prueba. CANACERO, México DF, México, 17 de agosto de 2013.

21 NMX-C-407-ONNCCE-2001 Industria de la construcción - Varilla corrugada de acero proveniente de lingote y palanquilla para refuerzo de concreto - especificaciones y métodos de prueba. Organismo Nacional de Normalización y Certificación de la Construcción y Edificación, S.C., México DF, México, 26 de julio de 2001.

22 PNTP 3391862015 Productos de acero. Barras y rollos de acero de baja aleación, soldables y corrugadas, para refuerzo de concreto armado. Especificaciones. INACAL, Dirección de Normalización, Lima, Perú.

23 PNTP 3410312015 Productos de acero. Barras y rollos de acero al carbono corrugadas, para refuerzo de concreto armado. Especificaciones. INACAL, Dirección de Normalización, Lima, Perú. 
24 UNE 360652011 Barras corrugadas de acero soldable con características especiales de ductilidad para armaduras de hormigón armado. AENOR, Madrid, España, marzo 2011.

25 UNE 360682011 Barras corrugadas de acero soldable para uso estructural en armaduras de hormigón armado. AENOR, Madrid, España, marzo 2011.

26 CNS 560 A2006 Steel Bars for Concrete Reinforcement. Bureau of Standards, Metrology and Inspection, Taiwan, February 5, 2005.

27 TS 708 Nisan 2010 Steel for the reinforcement of concrete - Reinforcing steel (in Turkish). Türk Standardlari Enstitüsü, Ankara, Turkey, 2010.

28 BS 4449-2005 A2 2009 Steel for the reinforcement of concrete - Weldable reinforcing steel - Bar, coil and decoiled product - Specification. British Standard Institution, London, UK, 2009.

29 ASTM A615/A615M - 14 Standard Specification for Deformed and Plain Carbon-Steel Bars for Concrete Reinforcement. ASTM International, West Conshoshoken, USA.

30 ASTM A706/A706M - 14 Standard Specification for Deformed and Plain Low Alloy Steel Bars for Concrete Reinforcement. ASTM International, West Conshoshoken, USA.

31 TCVN 1651-2 2008 Steel for the reinforcement of concrete - Part 2 Ribbed bars (in Vietnamese). Directorate for Standard, Metrology, and Quality, Hanoi, Vietnam, 2008.

32 Allen, M. Quench and tempering: an unfamiliar process in North America. AISTech 2010 Proceedings Volume II, pp. 707-715.

33 Resolution 404/99, Secretary of Industry, Commerce and Mining, Buenos Aires, Argentina, June 16, 1999 (in Spanish).

34 Ecuador Technical Regulation RTE INEN 016 Steel products for reinforced concrete. Subsecretary of Quality, Quito, Ecuador, 26/01/2015 (in Spanish).

35 Madias, J.; Wright, M.; Wolkowicz, P.; Reinforcing Bar: Hardening Mechanisms and Performance in Use. AISTech 2016 Proceedings, pp. 2287-2296.

36 Practice Advisory 11Grade 500E reinforcing steel. Good practice. Department of Building and Housing, December 2009.

37 BetonStahIVerzeichnisse. Deutsches Institut für Bautechnik, Berlin, Deutschland, April 13, 2015 (in German). 